\title{
The Right to State Lands a Study of a Squatter Community in Egypt
}

\author{
Salwa Salman
}

The American University in Cairo

\begin{abstract}
In 2016 'People's Right' Campaign, also known as the National Committee for Retrieving Looted State Lands, was assigned to either retrieve state lands or facilitate the formal registration of lands according to occupants' personal cases. This study draws on theories of discourse to explore official representations of desert land reclamation, allocation, and distribution, with a focus on the (re-) conceptualization of rights, state territoriality, and sovereignty as a part of narratives on state lands, property rights, and desert development. The study draws on methodological insights in the anthropology of development which employs a Foucauldian discourse analysis to examine 'development' and the role of the state under neoliberalism. Through the lens of a squatter settlement, Ard Baza, the study puts national narratives of desert development between 1952 and 2011 and property rights in conversation with individual cases to explore property and state/society relations.
\end{abstract}

Keywords: State lands, property rights, desert development, neoliberalism, squatter settlement.

\section{Introduction}

A wave of demolition and confiscation orders targeting extra-legal structures has been taking the lands of Egypt by storm. Under the banner of 'People's Right'; a committee responsible for retrieving looted state lands was established in February 2016 to mediate between squatters and state institutions, ğehāt elwelāyāh. On 29 May 2016, the settlers of Ard Baza waited anxiously in a packed storeroom, a few meters away from the service road parallel to Cairo-Alexandria desert highway, for the 'People's Right' Committee representative to arrive. Plot-owners, who were obviously meeting for the first time, discussed their disputes against the land broker, Baza, over services and fraudulent contracts. A few hours later, the representative arrived, greeted the settlers and explained briefly the method through which they can apply for reconciliation with the state.

The sounds of police cars sirens getting louder drew the settlers' attention to the military and police forces approaching the gate of the settlement, and within seconds settlers were moving their cars in front of their property to block the passage of the forces. On the top of a military tank were the Commissioner of Wadi El-Natrun Police Station and a representative from the General Authority for Reclamation Projects and Agricultural Development, GARPAD. The GARPAD official who claimed ownership of the land led the forces to demolish unpermitted buildings. Stopped by the committee's representative, the two state representatives argued over whether the settlement should be demolished. Finally, the committee's officer climbed up a police jeep leading military tanks and bulldozers to Baza`s two-story house and an abandoned building on the entryway of the settlement that was both doomed to demolition. 


\subsection{The Question of $M \bar{u} w \bar{a} t$ / Desert State Lands}

In his speech during the inauguration of several projects in the governorate of Qena, President Al-Sisi urged the police and the military to end illegal land acquisition . . . The President criticized the performance of the government urging it to improve and forcefully settle the legal status of land taken by force from the state.

Egypt Daily News, 31 May 2017.

On 9 February 2016, the President of Egypt issued Decree No. 75, to establish The National Committee for Retrieving Looted State Lands under the presidency of Ibrahim Mehleb, president's advisor for national projects and former Prime Minister (People's Right, 2017). The decree assigned the committee to calculate and recover unlawfully seized state lands; collect state dues and coordinate with authorities to retrieve looted lands; prepare reports of land grab cases; and transfer cases of looting state lands to national investigation bodies. Another Presidential Decree issued on 24 August 2017, announced that the recommendations of the committee are obligatory to all-state authorities (Ibid).

The Egyptian state has maintained a monopoly over lands, namely desert lands, from as early as the seventeenth and eighteenth centuries (Baer, 1962). The ambiguity of both the right of individuals to own desert lands and that of the state in Egypt's property law has led to several disputes between the state and members of the society. A recent research by the Egyptian Center for Policy Studies (2015) notes that ninety-six percent of Egypt's lands are categorized as desert lands that are directly owned by the state, most of which are informally occupied. The specificity of desert lands emerges from its unique position in the Egyptian Property Law, customary law, and the official development narrative which separates it from other types of lands. David Sims (2014) lists four categories of lands, (1) public-domain lands including military lands; (2) state private-domain lands, 'Amlāk 'amiriyāh; (3) private lands; (4) religious trust lands or waqf. In a report published in 2008 on "Landownership Disputes in Egypt- A Case Study on the Tensions Around the Monastery of Aby Fana in May 2008," the authors defines six categories of state lands among which are, (1) lands of strategic importance; (2) lands within a state-reclamation plan; (3) lands appropriated for the Ministry of Housing under the New Urban Societies' authority; (4) touristic areas; (5) lands for agricultural development (inside governorates' administrative borders); (6) lands outside of governorates' administrative borders (Johannsen et al, 2008, p.21) . Desert lands, in the Egyptian context, are state lands that extend outside of governorates' borders. According to Richard A. Debs in Islamic Law and Civil Code: The Law of Property in Egypt (2010), such categorization is driven from Sharia, he states that:

The only category of state-owned land that is separately treated in the Civil Code and that is traceable to traditional Islamic law is uncultivated land that has no owner and that may be acquired pursuant to the rules on appropriation. These lands apparently continue to be treated as a separate category of state-owned land distinct from either the private domain or the public domain. They are in effect, the (mūwät) lands of Islamic law" (p.136).

Along similar lines, Sims illustrates that "absent from all of these laws [public/ state lands laws] is the uplifting phrase, so common in similar legislation in other countries, that the public land is an asset that belongs to the people and is 'held in trust' by the state for the benefit of these people" (p.265). The way in which Egypt's property law deals with the possession of desert state lands is still ambiguous and put desert dwellers in a precarious situation where they're continuously haunted by the threat of eviction and demolition. The status of wad' yadd, a process where individuals can gain ownership over a desert land through cultivation and peaceful occupation, is one dimension of this ambiguity that adds to an incoherent legal landscape in treating desert properties and state lands in general. Gabriel Baer posits that the 
main distinction between state property and public property is that "ownership of the former may be transferred to individuals; ownership of the latter may not" (p.196).

The transaction of lands from the state domain to the private domain is appropriated through both formal registration and customary land ownership, in "Landownership Disputes in Egypt," the authors define two customary methods through which individuals claim desert state lands either through unregistered 'urfi contracts between two parties outside of the formal registration system or through wad 'yadd "(...) the seizure of a piece of land without any legal documents" (Johannsen et al. 7). However, the distinction between formal land registration and customary land ownership in Egypt's property law, especially in the case of state lands (agricultural and desert), is more complicated in both Egypt's property/legal discourse and in practice, for instance, Sims illustrates that the system under which the acquisition of uncultivated lands is regulated in the Civil Code have led to a 'legal problem,' "one part of the code recognizes the right to claim (through $\mathrm{wad}^{\prime}$ ' al-yadd) unused land and cultivate it and, after a period of fifteen years of peaceful, unchallenged, and uninterrupted possession gain ownership ... elsewhere in the code it states that such a right does not apply to state lands" (P.265). In this framework, two main laws regulate individuals' access to desert state lands, The Desert Lands Law of 1981 and State Private Property Law, modified in 2017.

\subsection{Research Focus and Questions}

This study draws on theories of discourse to explore official representations of state/ desert land reclamation, with a focus on the (re-) conceptualization of land rights, state territoriality, and sovereignty as a part of an emerging national narrative on state lands and property rights. Through the lens of an unregistered settlement, the study explores individual cases to explore property relations and state/society relations. With a focus on the period between 1989 and 2016. In this context, the study examines a sample of land contracts between state institutions and settlers and legal documents related to land ownership disputes. The main argument of this study lies at the juncture of two views on inclusiveness which are presented in David Harvey's 'Right to the City' and debates on property rights as a part of a national/ international legal discourse, it hypothesize that while non-hierarchical inclusiveness can be attained in the presence of strong social movements, the current jeopardized situation of Egypt's social movements calls for alternative forms of resistance, in this framework, I argue that such resistance should be directed towards re-investigating the right of the state to hold property under what comes to resemble a private property right. The main questions that guide this research are how have the Egyptian state used and portrayed secure property rights to encourage voluntary resettlement and investment in desert lands? What were the main shifts in the official narrative, and how can these shifts be read in the broader economic and political framework? How can studying desert reclamation contribute to the general understanding of the dynamics of property and state/society relations? What are the legal and customary frameworks that regulate the right to desert lands in Egypt? Ans how do legal agreements and local resource management influence collective action and resistance in squatter and informal communities? 


\section{Research Methods}

This study examines social relations that emerge around contractual agreements and managing resources such as water and electricity. To do so, it employs the following research methods:

(1) Participant observation: As a resident at Ard Baza I've dedicated three months to observe my routinely participation in Ard Baza, in the text I emphasize on occasions and incidents which highlight the power dynamics, along with, state/individual relations.

(2) In-depth interviews with thirteen members of Ard Baza settlement. The interviews were taped and translated in detail to examine the narratives and representation of the settler's land ownership, hand claims, and the registration process. Questions were structured to examine the process of registering a squatter settlement through the lens of individual cases to cast a light on broader contexts, such as the dynamics of competition over property in Egypt, desert development narratives, policies, and practices, state/society relationships, resource management and social networking in informal areas.

\subsection{Area of Study}

Ard Baza is a semi-formal settlement located on kilometer 91 from Cairo west of CairoAlexandria desert road, Baza, the original landowner and a retired public officer at Sadat City Council, bought the land (215 feddans ${ }^{1}$ ) in 1989 and have been selling small plots that range between few meters to feddan since the 1990s. Before Baza bought the land, it was allocated to Sadat City Authority, under the Ministry of Housing, Utilities, and Urban Development, and in 2002 Ard Baza was transferred to The General Authority for Reclamation Projects and Agricultural Development under the Ministry of Agriculture and Land Reclamation. The Ministry of Agriculture issued the first demolition order against Ard Baza in 2011, followed by another in 2014, and after the establishment of the People's Right Committee, a representative from the committee arrived at Ard Baza to stop the demolition order. With a very small population of about 20 resident families, Ard Baza does not provide much insight into the daily struggle of squatter populations, however, with over 200 plot-holders, the case of Ard Baza is an example of a growing form of investment by low-income and middle-income individuals in semi-formal lands and desert reclamation activities.

\section{Theoretical Debates and Considerations}

Former Prime Minister, Ibrahim Mehleb, invited Hernando de Soto, Peruvian development economist and President of the nongovernmental Institute of Liberty and Democracy (ILD), to discuss the possibility of reforming Egypt's property system and retain the value of a growing informal property sector in January 2015 (Al-Masry Al-Youm, 2015). Earlier in 1997, de Soto published a study in cooperation with The Egyptian Centre for Economic Studies on "Dead Capital and the Poor in Egypt" where they estimated an average loss of 241 billion US dollars in rural, urban and desert informal sectors dead capital mainly due to the high cost and complexity of land registration, a process that requires more than seventy-seven 'bureaucratic procedures' during the span of six to fourteen years. He proclaims that “(...) the problem that Egyptians will face is that most property in the informal sector cannot be documented and permanently inserted into the legal and global market economy by traditional titling, registration, surveying, mapping and privatization approaches" (p.2). De Soto lists six steps towards reforming Egypt's property registration system that start with (1) identifying the main challenges to formal registration and collecting information on the informal property market;

\footnotetext{
${ }^{1}$ One feddan is equal to 1.038 acres.
} 
(2) implementing an administrative and institutional reform strategy; (3) 'collect proofs of ownership'; (4) establishing a 'communication strategy' to raise awareness among informal communities; (5) developing the 'registry, surveying, and , mapping technologies'; finally (6) integrating the informal sector (Ibid, p.30-35).

De Soto's work has contributed to shaping market-led reform strategies in several countries of the global south. As development economists and a long-term international adviser to several 'underdeveloped' countries, he has been engaged in reform debates since 1997 under Mubarak's regime. In a talk under the title "Thoughts on the Importance of Boundaries," in 2013, he describes the Arab Spring as a wave of entrepreneurial revolts and proclaims that "we [the ILD] were hired by the Muslim Brotherhood to bring entrepreneurship to the poor in Egypt." A major critique of de Soto's thesis is premised on his strong advocacy for the commodification of property while overlooking patterns of exclusion that emerge from marketled reforms. Even within market-oriented framework and line of thought, several researchers proved that the formalization of the property will not lead to the increased access to credit and other financial services, it also does not facilitate national land transactions. $l$ : Land Tenure and Poverty in Africa and the Caribbean, a collection of empirical-oriented studies that test de Soto's thesis in a local context, researchers highlight three key limitations to de Soto's argument including the "(...) role of colonial and postcolonial governments in constructing exclusion and illegality" (Home \& Lim, 2004, p.149), assuming that investment and access to property loans are the main scopes of poor property holders, and underestimating state corruption as an obstacle to securing property rights.

R. Home and H. Lim posits that "the magic of property turns sand to gold is an aphorism that aptly encapsulates the de Soto thesis and current policies of the World Bank, USAID (,) and other aid agencies" (p.11). They portray de Soto's thesis as a 'magic bullet' that has disturbed a long silence over violations of security of land tenure and the precarious living conditions of communities that exist on the margins of the legal system. However, the question that the authors pose is whether land titling will secure tenure rights or not.

In 1986, the UN's Declaration on the Right to Development defines the 'right to development' as a social, economic and political progress of populations and as a primary human right, where the mechanisms of integration and equal access to development are set and governed by states. The 'right to development' has been the basis for different UN campaigns one of which is the right to 'secure tenure', adopted by the UN Centre for Human Settlement Program in 1999, to help states set a legal framework to facilitate land registration and ensure a secure base of rights to slum dwellers. Caroline Runkel (2004) examines the GTZ's, German Organization for Technical Cooperation, involvement in a titling project that aimed at legalizing property in Manshiet Nasser in 2009; she closely examines three cases of land titling that took place between 1976 and 1998, including, Helwan Housing and Community Upgrading project (19761988), Hayy Al-Salam in Ismailia (1978-1983), and Nasriyya in Aswan (1987-1998). Runkel points out that squatters have generally shown a lack of interest in titling their property due to the lack of trust in the effectiveness of the titling process, "(...) does the government really want to sell the land? Or is opening an ineffective titling process [,] a compromise that will ostensibly welcome GTZ's work and at the same time hold the government out of this risky affair?" (p.106).

The extent to which land titling will guarantee security of land tenure is questionable, however, in the light of a broader critical discussion on land deals in postcolonial countries, several scholars have pointed out to land titling is a process through which a state reconfigures its' sovereignty, authority, and territoriality; Home asserts that "not only is the modern nation-State partly defined by its territorial claims to sovereignty, but the construction and exercise of State 
power takes place within this territory, giving spatial geography a heightened significance in most of the State's activities" (Home \& Lim, p.16). Hence, the regularization of access to land, power to allocate, and to re-define rights become essential to state-building in this context, "it was argued that land grabs were happening in states where 'governance of the land sector and tenure security are weak" (Wolford et al, 2013, p.190), authors' instead highlight state's role in facilitating illegal occupation of lands for the benefit of capital-induced projects rather than the benefit of locals.

At this juncture, the retrieval of state lands contest themes of development and empowerment that have occupied official representations of desert reclamation and land allocation since the enactment of the First Land Reform Bill in 1952. Both bodies of literature do not expand on the concept of ownership from a legal and socioeconomic viewpoint, another pitfall of the above-examined literature is its failure to illustrate the cultural aspect of ownership and the specificity of the Egyptian local reclamation and land distribution experience, in this framework, this study expands on the local aspect of desert reclamation, distribution, and the concept of informality in Egypt.

David Harvey's 'Right to the City' and Hernando de Soto's thesis on Dead Capital are two opposite takes on the concept of rights, while Harvey explores the right to public spaces and inclusion in the urban process de Soto examines the right of low -income populations in secure tenure, in other words, their right in private property. Following a Marxist interpretation of capital accumulation, Harvey highlights the role of property market in surplus absorption and accumulation by dispossession, which is one of the basis of modern class struggle. While Harvey argues that resistance for dispossession is a role to be carried out through collective resistance, De Soto, on the other hand, analyses another form of dispossession that is based on the absence of legal rights to assets that are occupied by the poor, which is in other words, the absence of an inclusive property registration system, 'property registration'.De Soto portrays the lack of property representations as follows, "imagine a country where nobody can identify who owns what, addresses cannot be easily verified, people cannot be made to pay their debts, resources cannot conveniently be turned into money, ownership cannot be divided through documents" (De Soto, 2002, p.349).

As mentioned earlier, while de Soto emphasises on the importance of property representation to secure low-income populations' tenure rights and promotes as the right to economic power through recognition and formalization of property, he premises his rationalization of the formalization of property system is based on an advocacy for market-induced reforms, which leads us back to accumulation by dispossession and the triumph of radicalized capitalism, space modification, and unjust distribution of resources. Since property debates are always used in a context where different political ideologies dominates its' examination, in my own reading, while de Soto draws on an important aspect that is overlooked in many critical analysis, which is people's right to secure property, his analysis only advocates for property registration for the purpose of the inclusion of low-income society in the capitalist machine, the commodification of resources, where new forms of accumulation by dispossession emerge and develop.

\section{Contextualizing the History of Ard Baza}

\subsection{A Chain of Titles: Land Transaction(s) and Development}

In 1978, the President of Egypt issued Decree No. 123 to allocate119 thousand feddān of state lands on Cairo-Alexandria desert road under the administration of Beheira governorate, extending from kilometre eighty-four from Cairo to kilometre 110, to the Ministry of Housing to establish a City that was named after the President of Egypt Anwar el-Sadat, Sadat City. Commenced as an agro-industrial city, the Ministry of Housing allocated the desert lands 
surrounding Sadat to individuals and companies who were assigned to use the land for agricultural purposes, adding up to what was then a growing green belt surrounding Egypt's cities; "when the new towns of $6^{\text {th }}$ [of] October $10^{\text {th }}$ [of] Ramadan, and Sadat were designed in the late 1970s, there was a vision to surround these emerging cities with a green belt [to preserve environmental balance]" (Ezzat, 2011).

In July 1989, Sadat City Authority allocated 106 feddans to Baza, a retired officer at Sadat City Authority, who bought the land at a public auction under the condition that he uses it only for agriculture or food security projects; however, Baza started selling small plots of land to individuals and rent other plots to companies from as early as the year 1990, using the record, $m \bar{a} h d \bar{a} r$, as a proof of ownership. Baza, who is originally from Monufia Governorate, and moved to Sadat City in the 1970s to work as a public servant in the City Authority. Baza bought the land after his retirement under his title, his wife's, two sons, and daughter, in a phone interview with his son, a 35 years old lawyer who manages the family business including the land and electrical supplies shops in Sadat, he states:

We bought the land in the 80s when we first came, the land was not leveled, and had no water or electrical supply, we worked hard to provide the needed facilities to sell the land. First, we dug a well, and we bought an electrical transmitter that cost us about 90,000 Egyptian pounds. . . I was still young when my father bought the land, but I remember it was a wasteland full of snakes, we have worked a lot to make the land suitable for living. . . we first sold lands per feddans, but a lot of people were not capable to buy a whole feddān, so we started selling smaller tracts of lands.

In 2002, the land originally allocated to Sadat City east of the Cairo-Alexandria desert road, including Ard Baza, was demarked as a part of the Wadi el-Natrun, Beheira governorate. According to which, land management was transferred from Sadat City Authority to the GARPAD, established in 1975, which operates under The Ministry of Agriculture and Land Reclamation. Among the many predicaments that resulted from the new administrative division, was the invalidation of the contract between Baza and Sadat City Authority. As a result, Baza was obliged to sign a new contract with the GARPAD for only ninety-four feddans as a hand claimer wad' yadd.

The primary, 'urfi or ibtida'y, contract included the following terms and conditions:(1) the signer agrees to the terms and conditions of the contract; (2) the first party (the state) sold an area of ninety-four feddans to the second party (Baza); (3) the price of the land is 200 Egyptian Pounds per-feddān; (4) the second party vows to use the land for agricultural purposes; (5) the second party is obliged to use drip irrigation and sprinklers; (6) the second party agrees to provide water for irrigation; (7) the second party is committed to hand over the property and the contract will be cancelled if the land is required by any governmental authority within five years from signing the contract, however, the second party can negotiate with the governmental authorities to get a compensation for their property; (8) the second party is obliged to preserve state mines, quarries, mineral, and oil wealth;(9) the second party is obliged to plan roads, irrigation and sanitation networks within the boundaries of the land ;(10) the second party is committed to handing over the land, including the property and the facilities to the first party [GARPAD] in case the contract is cancelled; (11) the second party is obliged not to exceed the limits of land ownership stipulated by law No. 143 of 1981;(12) it is prohibited to sell or rent the land before seven years from the date of paying full land price; (13) the first party is to notify the Real Estate Taxes Commission upon signing the contract; (14) the provisions of Law No. 143 of 1982 (Desert Land Ownership Law) and the executive regulations under decree 198 of year 1982 (State's Private Property Law), apply to this contract. 
As noted before, according to Law 143 of 1981, desert land transactions between the state and individuals, as well as among individuals, is regulated by the Egyptian Civil Law, unlike the case of other forms of public property (for example military lands), desert lands' contractual rights does not fall under the concept of contracts of submission, $I \underline{d}$ 'an. In the above-mentioned case, the primary agreement between the state institution (GARPAD) and Baza is only a temporary agreement that should have eventually led to ownership, however, according to a research that The Egyptian Centre for Policy Studies conducted in 2015, the transaction of desert state lands to individuals is rarely completed which leaves settlers in a precarious situation since the termination of the contract can be directly executed by the administrative body to which the land is allocated (GARPAD) in this case, without further juridical review.

\subsubsection{The Termination of Baza's Contract}

Throughout the 90s Baza sold plots of lands that do not exceed one feddān each to individuals, after the land was transferred to GARPAD and resold to Baza in 2003, Baza started further fragmenting the land and selling tracts to individuals per-meter, who mostly used the land for residential purposes, Baza have also informally occupied 121 feddans between 2003 and 2014; consequently, on 8 September 2014 the Property and Disposition Department of GARPAD sent a letter to the Commissioner of Wadi El-Natrun police station urging him to carry out the Minister of Agriculture and Land Reclamation's order concerning the demolition of illegal buildings on Ard Baza upon the termination of the contract between him and the GARPAD due to changing the land use that was agreed upon from agricultural to residential purposes. The demolition order was first of three orders that were reprieved for 'impossibility of implementation since some families permanently reside on Ard Baza.

On 8 September 2014, the GARPAD sent the Commissioner of Wadi El-Natrun Police Station a letter pointing out to the issuance of a several demolition orders by the Minister of Agriculture against Ard Baza, the order was not executed, however, in 2016 the 'People's Right' campaign executed the order on two buildings in Ard Baza.

\section{Conclusion}

During the 1950s and 60s, collective ownership was promoted by Nasser's political elite as a tool for empowering peasants, the adoption of the set of economic liberation policies during the 1970s, known as the Open-Door policies, entailed a different form of landed resource management, especially in the case of New Lands' development. El 'ard lemān yazr' hā or "land to the tiller," was the government's slogan throughout the $1970 \mathrm{~s}, 80 \mathrm{~s}$, and $90 \mathrm{~s}$, to encourage farmers and graduates to reclaim desert lands. The unintelligibility of land registration system, among other factors, have led to a boom in wad ' $y$ add or hand claims.

Following the 2011 revolution, the involvement of businessmen and Mubarak's family in land deals was an issue which occupied much of the post-revolution debates on the corruption of the old system, Mitchel (2014) highlights in his forword to D. Sims's "Egypt's Desert Dreams: Development or Disaster?" that:

The fall of the Mubarak regime allowed a fuller exposure of the regime's mode of operation: The vast areas of public land allocated to private interests at low prices, the unauthorized taking of tens of thousands of acres of desert land, the waste of extraordinary quantities of public funds in building infrastructure for ill-conceived mega-projects that had failed to produce effective results, and the revenues lost in the disorganized and unregulated privatization of public assets (p.6). 
As a result, in 2016 President Sisi ordered the establishment of the 'People's Right' campaign in the name of retrieving looted state lands, the establishment of the committee was celebrated in the mainstream official media as a step towards fighting a long heritage of corruption, however, the execution of demolition orders against low-income squatter settlements and the recent presidential orders to once again transfer the cases of legalizing informal desert settlement to the local city councils mahalyiat which have a long legacy of corruption, puts the efficiency of the newly enacted policy of retrieving state lands into question.

\section{A Policy Mess: Chaos or 'Accumulation by Dispossession'?}

While the Egyptian government has attempted to empower the peasants in the 1950s and 60s through the implementation of the two agrarian reform bills in 1952 and 1961, the reforms were both flawed and short-lived; only few of the landless peasants that have acquired lands under the first two reforms were granted final sales contracts, where the state still maintained its monopoly over the lands and right of disposition. The history of Egypt's property system has been occupied by inconsistent policies that reflect on broader economic and policy-making reality.

This study reflects on the legal dilemma of desert land acquisition, a dimension that adds up to the desert mess, the question here is whether this mess is a product of understudied policy reforms, or is an organized strategy for accumulation by dispossession? To answer this question, I have examined the case of Ard Baza to analyze the social reaction to the 'People's Right' campaign and an emerging narrative on state ownership. The portrayal of the lands in both official narratives and local narratives, reflect on two distinct conceptions of ownership. The 'People's Right' campaign, like many other land reforms that have served short-lived political and institutional interests, is portraying the retrieval of state lands to the public as panacea while mystifying the main root of the problem, which is much related to the incomprehensiveness of the rules that govern individuals' access to desert / state lands. Another aspect of the problem is represented in the category of private state's property. Debs (2010) posits that state property (public property) as excerpted from the French Civil Code refers to the state as a "trustees of public interest,"another excerption that is employed in Egypt's property law is extracted from the Islamic Hanafi doctrine, entitles the state of full ownership over specific types of lands, e.g. mūwāt lands (Horri, 2011). However, at the present time the state's unlimited right to dispose of lands, namely desert lands, poses a multi-dimensional challenge, one that hinders both security of tenure and shrinks public space.

The Egyptian military's monopoly over decision making concerning the dispossession of state lands, according to Law 143 of 1981, is another aspect of the problem. R. Mason (2016), delves into the dynamics of the military economy given the very few resources available on military involvement in the formal economy, he posits that "the constitution [also] omits any reference to civilian oversight of the armed forces, in general, or regarding specific economic activities such as selling land and assets" (p. 83). In the Communist Manifesto, Marx and F. Engels state that "the theory of the Communists may be summed up in the single sentence: Abolition of private property." This study argues that both private property and state property are two sides of the same coin, thus if we followed Marx's line of reasoning, one would also call for the abolition of private state property.

\section{Acknowledgment}

This paper is a summary of my master's thesis "Egypt's Desert Paradoxes, Promises, and Possibilities: A Study of Land Reclamation Policies along Cairo-Alexandria Desert Road". The research project was conducted under the supervisions of Prof. Sandrine Gambline (former Director of The Middle East Studies Center at The American University in Cairo), Dr. Mona 
Abaza (Professor of Sociology at The American University in Cairo), and Prof. Robert Mason (Director of The Middle East Studies Center at The American University in Cairo).

\section{References}

Adriansen, Hanne Kirstine, 2009. Land Reclamation in Egypt: A Study of Life in the New Lands. Geoforum 40.4, pp. 664-674.

Arezki, Rabah, Klaus Deininger, 2013. and Harris Selod. What Drives the global 'Land Rush?' The World Bank Economic Review 29.2, pp. 207-233.

Baer, Gabriel, (1962). A History of Landownership in Modern Egypt 1800-1950. Oxford University Press. Print.

Debs, Richard A., (2010). Islamic Law and Civil Code: The Law of Property in Egypt. Columbia University Press.

De Soto, Hernando, 1989. The Other Path. New York: Harper \& Row.

---, (2000). The Mystery of Capital: Why Capitalism Triumphs in the West and Fails Everywhere else. Basic Civitas Books.

---, (1997). Dead Capital and the Poor in Egypt. Cairo, Egypt: The Centre for Economic Studies. Print. Distinguished Lecture Series 11.

---, (2002). Law and Property Outside the West: A Few New Ideas About Fighting Poverty. Forum for Development Studies.

---. Thoughts on the Importance of Boundaries. Proceedings of the American Philosophical Society, Vol. 157, No. 1, pp. 22-31.

Expert to Help Egypt Develop Shantytowns (16 Apr. 2017). Al-Masry Al-Youm. Web.

Harvey, David, 2008. The right to the city. The City Reader, pp. 23-40.

---, 2003. New Imperialism, Oxford University Press.

---, 2004.The New Imperialism": Accumulation by Dispossession. Actuel Marx, pp. 71-90.

---, 2007.Neoliberalism as Creative Destruction. The Annals of the American Academy of Political and Social Science 610.1, pp. 21-44.

History of the Monastery. The Monastery of St. Macarius the Great: At Scetis (Wadi NatrunEgypt). Web.

Home, Robert and Hilary Lim, (2004). Demystifying the Mystery of Capital: Land Tenure and Poverty in Africa and the Caribbean. Cavendish Publishing Limited. Print.

Horii, Satoe., 2011. Pre-Emption and Private Land Ownership in Modern Egypt: No Revival of Islamic Legal Tradition.Islamic Law and Society 18.2, pp. 177-218.

Johannsen, Asger Toft, et. Al, 2008. Landownership Disputes in Egypt - A Case Study on the Tensions Around the Monastery of Aby Fana in May 2008. The Center for Arab West Understanding.

Mason, Robert, (2016). Egypt's Future: Status Quo, Incremental Growth or Regional Leadership? Middle East Policy, pp. 76-94.

Mitchell, Timothy, 1999. Dreamland: The Neoliberalism of Your Desires. Middle East Report, pp. 28-29.

Mitchells, Timothy foreword to David Sims's book Egypt's Desert Dreams: Development or Disaster? The American University in Cairo Press, 2014.

Runkel, Carolin (2009). The Role of Urban Land Titling in Slum Improvement-The Case of Cairo: A Critical Examination of the GTZ Land Titling Program in Manshiet Nasser. Berlin, pp. 64-66.

Sims, David E, (2014). Egypt's Desert Dreams: Development or Disaster? Cairo: The American University in Cairo Press, p. 265.

The United Nations (1948). Declaration on the Right to Development. Print.

The General Organization for Physical Planning, (5 Apr. 2017). Web. 9 Apr. 2017. 
"(The Opening of the Biggest Irrigation Station, a Power Station, and Transmitter Station to Facilitate Irrigating 4000 Feddān in Tahrir) إفتناح اكبر محطة رى فى مديرية التحرير ومحطة كهرباء ومحطة . Al Ahram [Cairo] 3 Aug. 1958. Print.

Wolford, Wendy et al, 2013. Governing Global Land Deals: The Role of the State in the Rush for Land. Development and Change, 2013. 